\title{
The Learning Process of Scientific Imagineering through AR in Order to Enhance STEM Literacy
}

\author{
http://dx.doi.org/10.3991/ijet.v11i07.5357 \\ Somsak Techakosit and Prachyanun Nilsook \\ King Mongkut's University of Technology North Bangkok, Bangkok, Thailand
}

\begin{abstract}
The aim of this research was to develop the learning process of Scientific Imagineering through Augmented Reality (AR) in order to enhance STEM literacy. The research methodology was divided into two phases: 1) the documents in the Imagineering process, the Scientific process, and the AR learning environment were synthesised to develop the learning process of Scientific Imagineering through AR to enhance STEM literacy; 2) the suitability of the learning process of Scientific Imagineering through AR in order to enhance STEM literacy was evaluated by 10 experts who hold doctoral degrees, work as university lecturers and have at least 10 years' experience. The experts consisted of four experts in STEM disciplinary subjects, three experts in science education and three experts in technological education. The results showed that the learning process of Scientific Imagineering through $A R$ to enhance STEM literacy consisted of the learning process of Scientific Imagineering and the AR learning environment. The learning process of Scientific Imagineering consisted of the six following steps: 1) imagine; 2) study and research; 3) design; 4) develop; 5) present; and 6) evaluate. The AR learning environment consists of six factors: 1) flexibility; 2) user's reaction; 3) educational efficiency enhancement; 4) learning convenience; 5) motivation building and 6) collaborative learning encouragement. According to the evaluation from the experts, it was shown that the experts strongly agreed on the developed learning process of Scientific Imagineering, the AR learning environment, and the learning process of Scientific Imagineering through AR can develop STEM literacy.
\end{abstract}

Index Terms-Augmented Reality, Scientific Imagineering, STEM literacy

\section{INTRODUCTION}

It is generally known that the current technology is evolving us towards a society of information or a knowledge society [1]. Social and economic development requires an education system provide young people with the skills and abilities that enable them to benefit from the emergence of new forms of social and economic development in order to contribute their knowledge to the system's core assets. These twenty-first century skills and abilities are more related to the needs of the economic and social development model that has been emerging for more than a century than what was suitable for the industrial society in the past [2]. The traditional view of literacy has generally covered the ability to read and write. However, today's literacy means more than this [3]. This change was caused by the way technology has increased the intensity and complexity of the literate environments, together with the requirements of the twenty-first century for a person to have the capacity to perform a wide range of knowledge skills by understanding these diverse, energetic and malleable characteristics [4]. The National Council of Teachers of English state that a person who wishes to be completely successful in a global society in the twenty-first century must be able to: 1) develop abilities and fluency with the tools of technology; 2) create international links across multiculturalism and relationships with others in order to define and solve problems cooperatively and strengthen the idea of independence; 3 ) design and share information for the global communities to meet a variety of purposes; 4) simulatenously manage, analyse, and synthesise a flow of diverse information; 5) create, critique, analyse, and evaluate multimedia texts; and 6) be collaborative in ethical responsibilities imposed by these complex environments [4].

\section{A. Scientific Imagineering}

Imagineering is a compound word, a combination of the two main words "imagine" and "engineering" [5]. Its history begins in 1942. Alcoa, the leading manufacturer of aluminum, used the word "Imagineering" in the company's aluminum advertising products, to show confidence in the power of the imagination of engineers in developing innovative uses of aluminum. It was also to describe the production of aluminum at low prices, its diversity, and the fact that it enabled people to use aluminum everywhere. As has been said, "Imagineering is letting your imagination soar, and then engineering it down to earth" [6]. After about a decade, Walt Disney's company studied Imagineering and developed it as a job skill by founding Walt Disney Imagineering (WDI) as the engineering department, which was responsible for the development and creation of the well-known Disneyland. This department uses the boundless imagination and creative engineering of Imagineers, who are full of creativity and have the ability to endlessly innovate [7] [8].

Imagineering can make fantasy a reality by creating what has not yet happened [9]. Currently, Imagineering is becoming increasingly important because of insufficient knowledge and skills. Imagineering can imagine and manage products and services that are useful for the consumers of tomorrow [7]. The Imagineering style of learning can offer various design principles that will be helpful in structuring a course's appeal, which exposes students to the real and the tangible [9]. Imagineering can also be applied in engineering fields such as education, business and urban planning [9], [10], [11]. For the education aspect, it can be said that the learning process of Imagineering refers to the learning process of idea management and inspiration, sparking a strategic and creative framework in order to enable the initiative of currently unavailable fan- 
tasies and dreams to become a reality with the act or invention to be used in everyday life, by either an individual or a group [9], [11], [12], [13], [14], [15], [16].

The scientific approach is a common format used for describing the process of scientists in the scientific quest [17], in which scientists ask and answer questions using a particular set of steps. This process can be adopted to create a scientific experience that is comprehensive and meaningful for students. At every step of the way, students conceptualise scientific support related knowledge because, in each step, students can use a variety of skills to discover new information about the concept of learning [18].

The learning process of Scientific Imagineering is a process of learning science. It is similar to the process of an Imagineer, who innovates and creates a miracle [19]. This is the output required of students in education in the twenty-first century in order for them to be successful in work and life. This is in accordance with the Framework for twenty-first century learning to determine the Imagineering emphasising the brain functioning in the left and right hemispheres [20]. Thus, in the development of the learning process of Scientific Imagineering will lead students to be successful in work and life in the twenty-first century.

\section{B. Augmented Reality}

Augmented Reality (AR) technology is a kind of Virtual Reality (VR) that allows the user to view the real world and a $3 \mathrm{D}$ virtual object that overlaps or combines with the real world [21]. Users are therefore able to combine the physical environment with the computer-designed virtual environment [22]. Additional digital input could be 2D or $3 \mathrm{D}$, such as an audio file, video or alphabetical information from which the users can gain additional information in the real world [23].

Pence has categorised the currently used AR into two main categories: 1) markerless AR, which applies the position date by telephone and vision detection to indicate the position and overlap the digital information, and 2) marker-based AR, which requires a specific label, such as a barcode, to identify a location [24]. Similarly, Cheng and Tsai categorised AR into 1) image-based AR and 2) location-based AR [25].

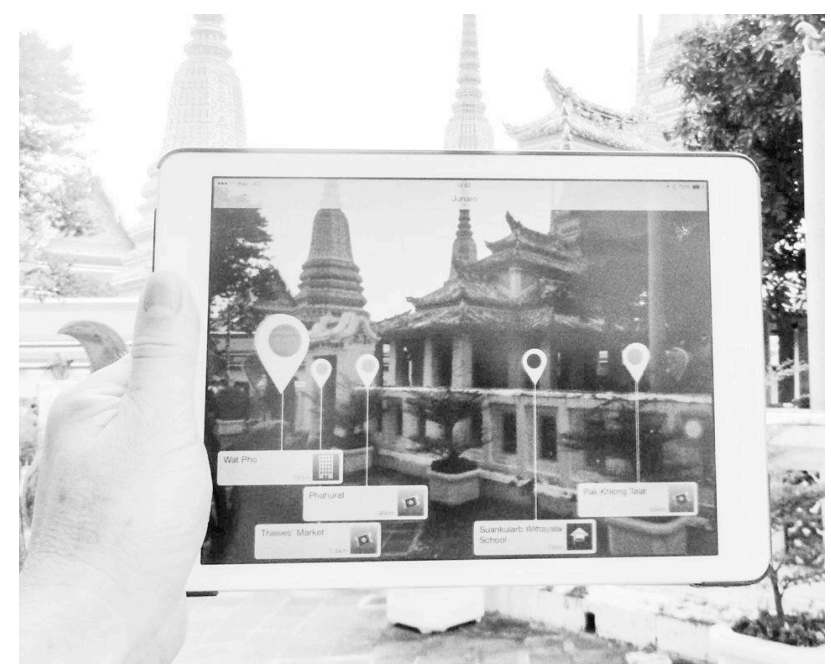

Figure 1. Junaio, an example of markerless AR
The advancement of current technology can escalate the effectiveness of AR yet reduce the size of related AR equipment such as smart-phones. Therefore, there is the possibility of using more AR in the future, especially within education [26]. The main advantage of AR, compared to traditional teaching methods, is that the learner can see and listen to additional information in digital form. Furthermore, it is also possible for learners to listen repeatedly [27]. Researchers have continuously developed educational AR, especially AR for the study of sciences or science education. Cheng and Tsai have reviewed research about the use of AR in the study of science and they found that learners' spatial ability, practical skills and conceptual understanding are often increased by image-based AR and location-based AR, which usually support inquiry-based scientific activities [25].

One of the most powerful technological developments within the last decade has been AR learning environments, which enable learners to use virtual objects in the real world [28]. The AR learning environment integrates real and virtual teaching environment and virtual teaching in a student-friendly and engaging manner. Tangible interfaces are the media used to enable students to examine and experiment with the virtual teaching material in a natural manner [27]. In AR, the real environment must be harmonised (and synchronised) with the virtual in position and context in order to provide an understandable and meaningful view [29].

\section{STEM literacy}

STEM is the abbreviation of science, technology, engineering and mathematics. The abbreviation was first used in 2001 by Judith A. Ramaley of the National Science Foundation. At present, STEM refers to an educational curriculum that integrates the fields of science, technology, engineering and mathematics. Ramaley defines STEM as the academic pursuit of learning in the context where students can resolve problems in the real world through the creation of opportunity and search for innovation [30].

STEM education is a programme for studying science, technology, engineering and mathematics in order to define the main objective of supporting or strengthening the rigid study of science, technology, engineer and mathematics from primary and secondary school up to the doctoral level, including adult education [31], both formally,

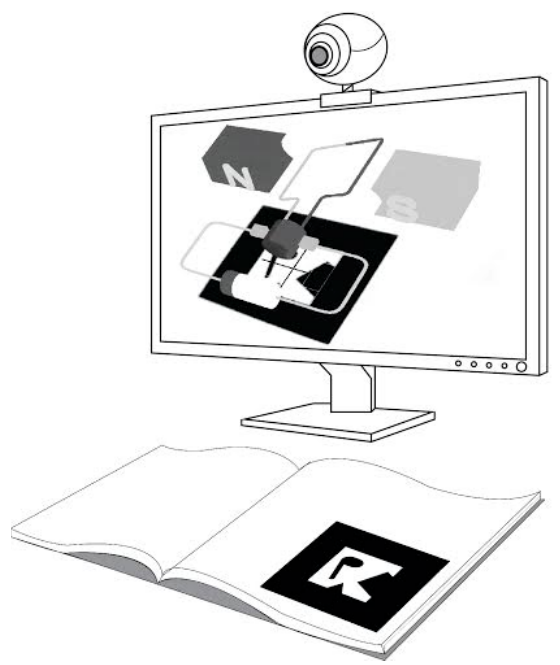

Figure 2. Marker-based AR. 
such as in a classroom, and informally, as in a post-school programme [32]. STEM study is an input that is prepared for learners where STEM literacy is an outcome that increases learners' development in knowledge, skills and attitude [33].

STEM literacy is important for students as a step towards their future career. It is at the core of the essential skills needed in the twenty-first century in order for the students to become high-level problem resolvers, innovators, technologists and engineers and to create an educated population [34]. STEM literacy refers to an individual's ability to apply his or her understanding of how the world works within and across four interrelated domains. STEM literacy does not simply mean achieving literacy in these four strands or silos [35].

\section{OBJECTIVE}

The purpose of this research was to develop the learning process of Scientific Imagineering through $A R$ in order to enhanced STEM literacy.

\section{Methodology}

The research methodology was divided into the two following phases;

Phase 1 The steps of designing the learning process of Scientific Imagineering through AR in order to enhance STEM literacy were as follows:

1) Complete a review of related literatures on the Imagineering process written by [8], [9], [16], [36], [37], [38], [39], [40] and [41] and those in the scientific process by [17], [42], [43] and [44] to create a new learning process called the learning procee Scientific Imagineering.

2) Synthesise documents in the AR learning environment, consisting of [23], [46], [47], [48], [49], [50], [51] and [52].

3) Develop the learning process of Scientific Imagineering through AR in order to enhance STEM literacy, consisting of learning process of Scientific Imagineering and AR learning environment.
Phase 2 The steps of evaluating the suitability of the learning process of Scientific Imagineering through Augmented Reality in order to enhance STEM literacy were as follows:

1) Create a tool for evaluating the suitability of the learning process of Scientific Imagineering through AR in order to enhance STEM literacy.

2) Propose the development of the learning process of Scientific Imagineering through AR in order to enhance STEM literacy to 10 experts who hold doctoral degrees, work as lecturers at universities and have at least 10 years' a relevant. These experts would consist of four experts in STEM disciplinary subjects, three experts in science education and three experts in technological education, who would consider and evaluate the suitability.

3) Analyse the results of the evaluation of the suitability of the learning process of Scientific Imagineering through AR in order to enhance STEM literacy by using the mean $(\bar{x})$ and standard deviation (S.D.). The five-point Likert scale would be used to determine the weight of assessing the appropriateness of the activity.

\section{RESULTS}

Documents in the Imagineering process and the scientific process were synthesised. The Imagineering process and the scientific process were synthesised to create a new learning process called the Scientific Imagineering process.

According to Table I, the synthetic learning process of Scientific Imagineering consists of six steps: 1) imagine; 2) study and research; 3) design; 4) develop; 5) present; and 6) evaluate. Each step is detailed below.

To imagine is the first step of the learning process of Scientific Imagineering. It is the beginning of the inspiration process, in which Guzdial and Tew suggest using with interesting stories [9] to inspire students to learn. Students observe things and find something compelling within them; and teachers can help them to define and explain what they observe [43]. Questioning is the procedure to be used. The question is an important characteris-

TABLE I.

THE SYNTHETIC LEARNING PROCESS OF SCIENTIFIC IMAGINEERING

\begin{tabular}{|c|c|c|c|c|c|c|c|c|c|c|c|c|c|}
\hline \multirow[b]{2}{*}{$\begin{array}{l}\text { The learning } \\
\text { process of Scien- } \\
\text { tific Imagineering }\end{array}$} & \multicolumn{9}{|c|}{ Imagineering process } & \multicolumn{4}{|c|}{ scientific process } \\
\hline & 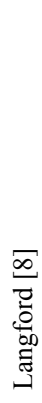 & 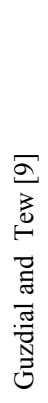 & 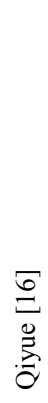 & 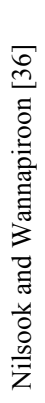 & 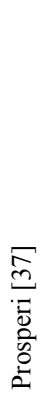 & 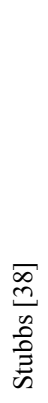 & 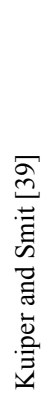 & 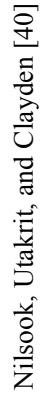 & 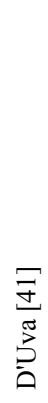 & 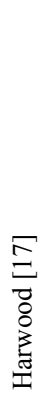 & $\begin{array}{l}\underset{J}{J} \\
\stackrel{\Xi}{\Xi}\end{array}$ & 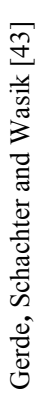 & 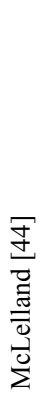 \\
\hline Imagine & $\checkmark$ & $\checkmark$ & $\checkmark$ & $\checkmark$ & $\checkmark$ & $\checkmark$ & $\checkmark$ & $\checkmark$ & & $\checkmark$ & $\checkmark$ & $\checkmark$ & $\checkmark$ \\
\hline Study and research & $\checkmark$ & $\checkmark$ & $\checkmark$ & & $\checkmark$ & $\checkmark$ & $\checkmark$ & & & $\checkmark$ & $\checkmark$ & $\checkmark$ & $\checkmark$ \\
\hline Design & & & & $\checkmark$ & $\checkmark$ & $\checkmark$ & $\checkmark$ & $\checkmark$ & $\checkmark$ & $\checkmark$ & $\checkmark$ & $\checkmark$ & $\checkmark$ \\
\hline Develop & & $\checkmark$ & & $\checkmark$ & $\checkmark$ & $\checkmark$ & $\checkmark$ & $\checkmark$ & $\checkmark$ & & & & \\
\hline Present & $\checkmark$ & $\checkmark$ & $\checkmark$ & $\checkmark$ & & & & $\checkmark$ & $\checkmark$ & $\checkmark$ & & $\checkmark$ & $\checkmark$ \\
\hline Evaluate & $\checkmark$ & & $\checkmark$ & $\checkmark$ & & & $\checkmark$ & $\checkmark$ & & & $\checkmark$ & & $\checkmark$ \\
\hline
\end{tabular}


tic in the scientific quest for knowledge [17], and the question; can be research driven. Brainstorming is a key aspect of Imagineering, in order to create a fantasy called "Blue Sky" as a state of mind without frame, where nothing is impossible. This helps children think of an idea to innovate without having to worry about whether it can happen or not [45]. Prosperi has suggested four brainstorming rules of Imagineering: 1) there is no idea that is impossible; 2) never ask the question "Why not" because there is plenty of time for the truth and we do not want to stop a good idea right now; 3) there is nothing to stop the flow of ideas apart from the words "but" or "could" or other words that stop thinking. Instead, use words such as "and" and "or" and questions such as "What will happen if...?"; and 4) there is no useless idea [37].

Study and research is a step in the quest for knowledge. It starts with the assumption that education is supposedly about something that will happen in a trial on the basis of research [42]. To make an assumption is to use deductive reasoning [44], which teachers will help students apply to what they observe; students will use their background knowledge to speculate about the answer [43]. The method for carrying out the study is via a variety of activities in order to choose the question, confirm validation, prepare material and collect data [17]. Teachers will pay attention to details in the lecture and prepare the learning equipment that students can apply to their own work [9]. AR is an educational technology that encourages students to learn more and further with flexible context deployment and it creates a variety methods for different learning [46]. Students can participate in activities that help them to answer questions, whereas teachers encourage students to participate in the formation of research questions, descriptions, model finding, comparison, collocation, measurements, and data management [43]. An examination of the results was conducted to ensure the correctness of information through repeated study, in order to reflect on the findings and link them to evidence that is already known [17].

Design is an initial process of changing concepts into reality [37]. D'Uva suggests that the process of the design project of Imagineering is as follows: 1) draw and write ideas on the board. The details of the idea should be as specific as possible but might not be complete; 2) present ideas to colleagues with confidence and clarity; 3 ) vote for the best idea; and 4) design the selected concept until completion [41]. The complete result of this process includes elevations, blue-prints, specification, plans, colour boards, etc. In the case of the study design, the result will be document design, detailed layout and the test plan [37].

Development is the process of bringing things from the design stage to create a real piece of work [9]. Nilsook and Wannapiroon state that the development process consists of creation and testing [36].

Presentation is the step in which students present their finding(s) to each other. The teachers can use various methods or types of media to allow the transferal of students' ideas [43] and to describe their processes and the technique of creating such products [44].

Evaluation is the step of making recommendations. Students should be able to suggest appropriate advice that they have developed or gained in completing their project, either from their work process or from product quality investigations. Students need to learn from previous case studies that have offered concrete results. Their selfmotivation will provide knowledge, which will remain with them [40].

The learning process of Scientific Imagineering is reproducible (the steps need to be repeated until all are done properly), with the purpose of applying the knowledge and insight gained to new tools to improve learning [39], leading to the expansion of student learning by eliciting new questions emerging from the attention of students [43].

The synthesis of documents in the AR learning environment, consisting of [23], [46], [47], [48], [49], [50], [51] and [52] is shown in Table II.

Based on the literature review of the AR learning environment, AR has six important characteristics: 1) flexibility; 2) interactivity; 3) educational efficiency enhancement; 4) learning convenience; 5) motivation building; and 6) collaborative learning encouragement.

TABLE II.

THE SYNTHETIC AR LEARNING ENVIRONMENT

\begin{tabular}{|c|c|c|c|c|c|c|c|c|}
\hline AR learning environment & 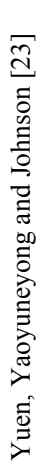 & 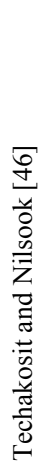 & 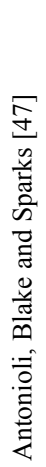 & 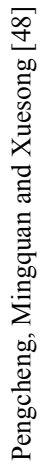 & 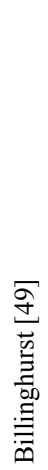 & 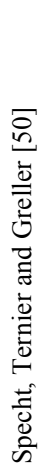 & 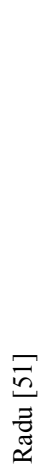 & 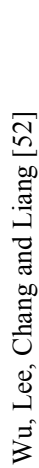 \\
\hline Flexibility & & $\checkmark$ & $\checkmark$ & $\checkmark$ & & & & $\checkmark$ \\
\hline Interactivity & & $\checkmark$ & & $\checkmark$ & $\checkmark$ & & & $\checkmark$ \\
\hline Learning efficiency enhancement & $\checkmark$ & $\checkmark$ & $\checkmark$ & $\checkmark$ & $\checkmark$ & $\checkmark$ & $\checkmark$ & $\checkmark$ \\
\hline More convenient learning & & $\checkmark$ & & $\checkmark$ & & & & $\checkmark$ \\
\hline Motivation building & $\checkmark$ & $\checkmark$ & & $\checkmark$ & & & $\checkmark$ & \\
\hline Collaborative learning encouragement & $\checkmark$ & & & & & & $\checkmark$ & $\checkmark$ \\
\hline
\end{tabular}


Flexibility: various AR learning environments could be used through various media such as desktops, mobile devices and smart-phones. It is possible to apply and adapt various learning situations and contexts [46], [47]. Teachers can apply AR in accordance with the needs of the curriculum and individual students [48]. AR will support students in bridging formal and informal learning [52].

Interactivity: the AR learning environment supports smooth relations between real and virtual environments [49], allowing students to control the process and add and reduce the factors in the AR-based experiment in order to gain different results from different experiments [48].

Learning efficiency enhancement: AR can be used for enhancing the effectiveness of content and teaching in the traditional style, including extending the context outside the classroom [47] rather than just using textbooks [48]. AR can also assist learners in understanding details [50] with a shorter learning time [46]. Research indicates that content learned through AR experiences is memorised more strongly than through non-AR experiences [51] because AR can assist students in viewing the lesson in 3D form [52].

More convenient learning: students can use AR as a tool for learning anywhere and anytime [46]. Also, teachers can use AR to demonstrate in their teaching more comfortably, as just a card with a special mark is needed, rather than overweight equipment or unnecessary tools, and this helps to prevent any unexpected incident and loss [48].

Motivation building: AR can take a virtual object into the real environment and make abstractions into realistic, ordinary things. This increased liveliness raises students' enthusiasm and pioneering sense, including an independence of study that will increase students' creativeness and imagination [48]. It also encourages students to learn more frequently [46].

Collaborative learning encouragement: the AR learning style can prompt and improve cooperation [51] both among students and between teachers and students [23].

According to the learning process of Scientific Imagineering and AR learning environment synthesis, it is possible to present the learning process of Scientific Imagineering through AR in order to enhance STEM literacy, as shown in Figure 3.

Figure 3 reveals that the learning process of Scientific Imagineering by AR to enhance STEM literacy consists of the learning process of Imagineering and the AR Learning Environment in such a way that AR can be used throughout the process of learning Scientific Imagineering, which will increase students' STEM literacy levels.

The results of the suitability of the learning process of Scientific Imagineering by AR to enhance STEM literacy, as evaluated and certified by 10 experts are as follows:

Table III show that the experts agreed on every step of the learning process, choosing "strongly agree". The table shows that there is a belief that learning begins with the imagination, as Einstein said that imagination is more important than knowledge. For the process of education and research, it is a process of inquiry, which is a way to learn the skills and knowledge for understanding and creation in the midst of rapid technological change [53]. In addition, the learning process of Scientific Imagineering is converted from tacit knowledge into working knowledge [54].

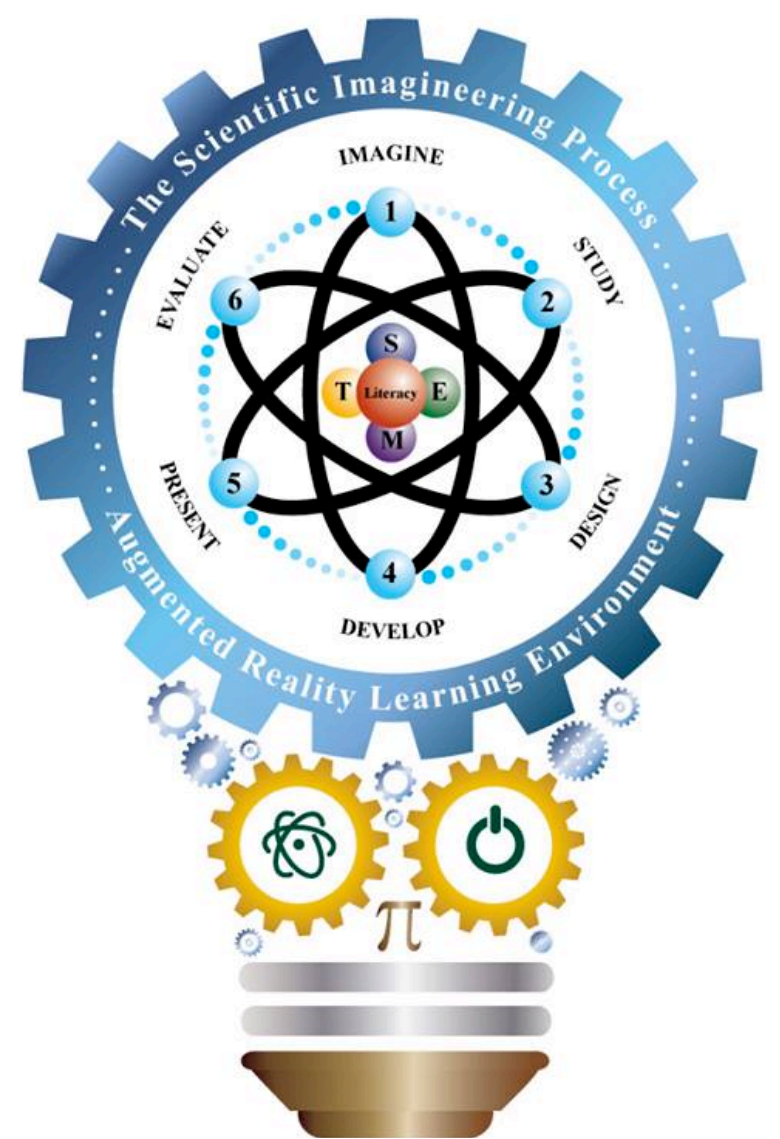

Figure 3. Learning process of Scientific Imagineering by AR to enhance STEM literacy

TABLE III.

The Results OF EVAluAting THE LEARNING PROCESS OF SCIENTIFIC IMAGINEERING

\begin{tabular}{|l|c|c|c|}
\hline $\begin{array}{c}\text { The learning process of } \\
\text { Scientific Imagineering }\end{array}$ & $\bar{x}$ & S.D. & $\begin{array}{c}\text { Level of } \\
\text { agreement }\end{array}$ \\
\hline Imagine & 4.70 & 0.48 & Strongly agree \\
\hline Study and research & 4.60 & 0.52 & Strongly agree \\
\hline Design & 4.50 & 0.53 & Strongly agree \\
\hline Develop & 4.40 & 0.52 & Agree \\
\hline Present & 4.60 & 0.52 & Strongly agree \\
\hline Evaluate & 4.40 & 0.52 & Agree \\
\hline
\end{tabular}

Table IV show that the experts agreed on the attributes of the AR learning environment. This demonstrates the potential of AR in that it has proved to be an engaging way for students to participate in their learning. This new technology enables the current learning to be studentcentred and it creates opportunities for collaboration that fosters a deeper understanding of the content [55].

Table V shows that the experts agreed that STEM literacy can be developed using the learning processes of Scientific Imagineering by AR, by choosing "strongly agree". This is because the learning process of Scientific Imagineering is a learning process in accordance with STEM classroom characteristics that promote the skill of higherorder thinking, problem solving and intellectual curiosity and it allows students to communicate ideas and information effectively and creatively [56], drawing students 
TABLE IV.

THE RESULTS OF EVALUATING THE AR LEARNING ENVIRONMENT

\begin{tabular}{|l|c|c|c|}
\hline \multicolumn{1}{|c|}{ AR learning environment } & $\bar{x}$ & S.D. & $\begin{array}{c}\text { Level of } \\
\text { agreement }\end{array}$ \\
\hline Flexibility & 4.30 & 0.67 & Agree \\
\hline Interactivity & 4.50 & 0.53 & Strongly agree \\
\hline $\begin{array}{l}\text { Learning efficiency en- } \\
\text { hancement }\end{array}$ & 4.60 & 0.52 & Strongly agree \\
\hline More convenient Learning & 4.50 & 0.71 & Strongly agree \\
\hline Motivation building & 4.70 & 0.48 & Strongly agree \\
\hline $\begin{array}{l}\text { Collaborative learning en- } \\
\text { couragement }\end{array}$ & 4.40 & 0.70 & Agree \\
\hline
\end{tabular}

TABLE V.

THE RESUlts OF EVALUATING THE LEARNING PROCESS OF SCIENTIFIC IMAGINEERING BY AUGMENTED REALITY TO ENHANCE STEM LITERACY

\begin{tabular}{|l|l|l|l|}
\hline \multicolumn{1}{|c|}{$\begin{array}{c}\text { The learning process of } \\
\text { Scientific Imagineering }\end{array}$} & $\bar{x}$ & S.D. & $\begin{array}{c}\text { Level of } \\
\text { agreement }\end{array}$ \\
\hline $\begin{array}{l}\text { STEM literacy can be en- } \\
\text { hanced by the learning } \\
\text { process of Scientific Imagi- } \\
\text { neering. }\end{array}$ & 4.50 & 0.71 & Strongly agree \\
\hline $\begin{array}{l}\text { STEM literacy can be en- } \\
\text { hanced by the AR learning } \\
\text { environment. }\end{array}$ & 4.50 & 0.71 & Strongly agree \\
\hline $\begin{array}{l}\text { STEM literacy can be en- } \\
\text { hanced by the learning } \\
\text { process of Scientific Imagi- } \\
\text { neering by AR. }\end{array}$ & 4.50 & 0.71 & Strongly agree \\
\hline
\end{tabular}

away from learning by rote conventional processes and toward a method that allows them to examine and question aspects of the world [35], which encourages students to become high-level innovators, technologists, engineers and people who have knowledge [34].

\section{CONCLUSION}

According to the document analysis that is associated with the process of Imagineering and science, together with $\mathrm{AR}$ in education, it was found that the learning process of Scientific Imagineering by AR to enhance STEM literacy consists of the learning process of Scientific Imagineering and the AR learning environment. The process of Scientific Imagineering consists of six phases: 1) imagine, which means to inspire students to learn through the observation of interesting things and includes setting the question of the nature of scientific inquiry. Brainstorming is an important characteristic of Imagineering; 2) study and research, beginning from an hypothesis that led to the study or testing it as the basis of research; 3) design: the first step of turning ideas into reality; 4) develop, which means working with something from the design stage to create a real piece of work; 5) present in order to share findings; and 6) evaluate and give a suggestions for the development of the process and the product.

The AR learning environment consists of six aspects: 1) flexibility; 2) user's reaction; 3) learning efficiency enhancement; 4) learning convenience; 5) motivation building; and 6) collaborative learning encouragement.

According to the evaluation from the experts, it was shown that the experts strongly agreed on the developed learning process of Scientific Imagineering, the AR learn- ing environment, and the learning process of Scientific Imagineering through AR can develop STEM literacy.

\section{ACKNOWLEDGMENTS}

This research received a partial thesis research grant for graduate students from the Graduate College at King Mongkut's University of Technology North Bangkok. I would like to express my sincere gratitude to the Vocational Education Technology Research Center of the Science and Technology Research Institute, King Mongkut's University of Technology North Bangkok, for supporting this research.

\section{REFERENCES}

[1] J. Voogt and N. P. Roblin, $21^{\text {st }}$ CENTURY SKILLS. AE Enschede: University of Twente, 2010.

[2] K. Ananiadou and M. Claro, " $21^{\text {st }}$ Century Skills and competences for New Millennium learners in OECD countries, OECD Education Working Paper, No. 41, OECD Publishing," 2009 [Online]. Available: http://dx.doi.org/10.1787/218525261154

[3] A. Zollman, "Learning for STEM Literacy: STEM Literacy for Learning," School Science and Mathematics, vol. 112, no. 1, 2012, pp. 12-19. http://dx.doi.org/10.1111/j.1949-8594.2012.00101.x

[4] National Council of Teachers of English, "The NCTE Definition of 21 st Century Literacies," 2013 [Online]. Available: http://www.ncte.org/ positions/statements/21 stcentdefinition.

[5] Walt Disney Imagineering, Walt Disney Imagineering: a Behind the Dreams Look at Making the Magic Real .China: Welcome Enterprises, Inc., 2010

[6] Alcoa, "The place they do Imagineering," Time, pp. 59, $16^{\text {th }}$ February 1942.

[7] S. Duncan, "Construction in the Imagineering classroom," 2011 [Online]. Available: https://secure.ccie.com/library/5019952.pdf.

[8] D. P. Langford, Imagineering. Tool Time Education. Montana: Langford International, Inc., 2010.

[9] M. Guzdial and A. E. Tew, "Imagineering Inauthentic Legitimate Peripheral Participation: An Instructional Design Approach for Motivating Computing Education," in Proc. ICER'06, 2006, pp. 51-58. http://dx.doi.org/10.1145/1151588.1151597

[10] J. Ratcliffe and E. Krawczyk, "Augmented reality in education: current technologies and the potential for education," Social and Behavioral Sciences, vol. 47, 2001, pp. 297-302.

[11] I. S. Pantelidis and G. Marée, "Imagineering the meal experience," EuroChrie Conference. Helsinki, 22-24 October (Refereed Working Paper). (2009).

[12] P. Jarvis and H. Esbin, "Getting Serious Play: Life Span Career Education," Education Canada, vol. 46, no. 3, 2010, pp. 46-48.

[13] R. Franjic, S. Favro, and M. Perišic, "System concept of experience in nautical tourism,"2012 ]Online]. Available: www.vern.hr/docs/Islands-.2012 10 10pdf.

[14] Walt Disney Imagineering, Walt Disney Imagineering: a Behind the Dreams Look at Making the Magic Real, New York: Hyperion, 1996.

[15] D. Nijs and Ir. J Van Engelen, "Imagineering as Complexity Inspired Method for Transformative Service Design," 2014 [Online]. Available: http://www.servdes.org/wp/wpcontent/uploads//2014 /06Nijs-D-Van-Engelen-Ir-J.pdf.

[16] F. Qiyue, "Imagineering. Business Innovation from the Experience Perspective," 2013 [Online]. Available: http://www.fongqiyue.com/ Imagineering_FongQiyue.pdf.

[17] W. S. Harwood, "A New Model for Inquiry Is the Scientific Method Dead?," Journal of College Science Teaching, vol. 33, no. 7, 2004, pp. 29-33.

[18] R. Gelman and K. Brenneman, "Relevant pathways for preschool science learning," Early Childhood Research Quarterly, vol. 19, 2004, pp. 150-158. http://dx.doi.org/10.1016/j.ecresq.2004.01.009

[19] Productions Imagineer, "Imagineer Production - Impact 2009 2014," 2014 [Online]. Available: http://www.imagineer productions.co.uk/resources/0000/1560/Imagineer Productions-Impact 2009 - 2014 long version FINAL.pdf. 
[20] Partnership for $21^{\text {st }}$ Century Skills, "Framework for $21^{\text {st }}$ Century Learning,” 2011 [Online]. Available: http://www.p21.org/ storage/ documents/1._p21_framework_2-pager.pdf.

[21] R. T. Azuma, "A survey of augmented reality," Presence: Teleoperators and Virtual Environments, vol. 6, no. 4, 1997, pp. 355385. http://dx.doi.org/10.1162/pres.1997.6.4.355

[22] T. Thornton, J. V. Ernst, and A. C. Clark, DTE., "Augmented Reality as a Visual and Spatial Learning Tool in Technology Education," Technology and Engineering Teacher, vol. 71, no. 8, 2012, pp. 18-21.

[23] S. Chi-Yin Yuen, G. Yaoyuneyong and E. Johnson, "Augmented Reality: An Overview and Five Directions for AR in Education," Journal of Educational Technology Development and Exchance, vol. 4, no. 1, 2011, pp. 119-140.

[24] H. E. Pence, "Smartphone, Smart Objects, and Augmented Reality," The Reference Librarian, vol. 52, no. 1, 2011, pp. 136-145.

[25] K. H. Cheng and C. C. Tsai, "Affordances of Augmented Reality in Science Learning: Suggestions for Future Research," J Sci Educ Techno, vol. 22, 2013, pp. 449-462. http://dx.doi.org/10.1007/ s10956-012-9405-9

[26] K. Lee, "Augmented Reality in Education and Training." TechTrends, vol. 56, no.2,2012 pp. 13-21. http://dx.doi.org/10.1007/s11528-012-0559-3

[27] F. Liarokapis, "Augmented Reality Interface for Assisting Computer Games University Students," Bulletin of the IEEE Technical Committee on Learning Technology, vol.14, no.4, 2012, pp.7-10.

[28] D. Ifenthaler and D. Eseryel, "Facilitating Complex Learning by Mobile Augmented Reality Learning Environments," In: R. Huang et al. (eds.), Reshaping Learning, New Frontiers of Educational Research, New York: 2013. http://dx.doi.org/10.1007/978-3-642-32301-0 18

[29] F. Liarokapis and E. F. Anderson, "Using Augmented Reality as a Medium to Assist Teaching in Higher Education," in Proc. the 31st Annual Conference of the European Association for Computer Graphics (Eurographics 2010), 2010, pp. 9-16.

[30] A. D. Watson and G. H. Watson, "Transitioning STEM to STEAM: Reformation of Engineering Education," 2013 [Online]. Availa-

ble:https://www.academia.edu/8766909/Transitioning_STEM_to_ STEAM_Reformation_of_Engineering_Education.

[31] The United States Department of Education, Report of the Academic Competitiveness Council. Washington, DC: Author, 2007.

[32] H. B. Gonzalez and J. J. Kuenzi, "Science, Technology, Engineering, and Mathematics (STEM) Education: A Primer," 2012 [Online]. Available: http://fas.org/sgp/crs/misc/R.42642pdf.

[33] H.Meeder, "What Is "STEM Literacy"?," 2014 [Online]. Available: http://nc3t.com/stem-literacy.

[34] ITEEA board of directors, "Proclamation: ITEEA's Position on the "T" \& "E" of STEM," 2009 [Online]. Available: http://www.iteaconnect.org/AboutITEEA/STEMProclamation.pdf.

[35] National Governors Association ,"Innovation America: Building a Science, Technology, Engineering and Math Agenda," 2007 [Online]. Available: http://www.nga.org/files/live/sites/NGA/files/ pdf/0702INNOVATIONSTEM.PDF.

[36] P. Nilsook and P. Wannapiroon, "Imagineering," Journal of Technical Education Development, vol. 25, no. 86, 2013, pp. 3337.

[37] L. J. Prosperi, “The Imagineering Model: Applying Disney Theme Park Design Principles to Instructional Design," 2014 [Online]. Available: http://www.slideshare.net/louprosperi1/the-imagineer ingmodel.

[38] S. T. Stubbs, "How Did You Manage to Do That? An Instructional Multimedia Production Management Process," Journal of Interactive Instruction Development, SPRING, 2002, pp. 25-32.

[39] G. Kuiper and B. Smit, Imagineering: innovation in the experience economy 2014. Croydon: CPI Group (UK) Ltd,2014.

[40] P. Nilsook, N. Utakrit, and J. Clayden, "Imagineering in Education: A Framework to Enhance Students' Learning Performance and Creativity in Thinking," educational technology, vol. 54, no.1, 2014, pp. 14-20.
[41] N. D'Uva, "Walt Disney Imagineering,” 2014 [Online]. Available: https://prezi.com/va6wlmn3-xe_/walt-disney-imagineering.

[42] C. Main, "Chemistry Sets: Teaching the Scientific Method," 2015 [Online]. Available: http://chemistry-sets-review.toptenreviews. com/chemistry-sets-teaching-the-scientific-method.html.

[43] H. K. Gerde, R. E. Schachter and B. A. Wasik, "Using the Scientific Method to Guide Learning: An Integrated Approach to Early Childhood Curriculum, " Early Childhood Educ J. (2013), vol. 41, 2013, pp. 315-323.

[44] C. V. McLelland, "Nature of Science and the Scientific Method," 2003 [Online]. Available: http://www.geosociety.org/educate/ Nature Science.pdf.

[45] G. Dehrer, "Imagineers in Search of the Future," The Futurist, March-April, 2011, pp. 36-42.

[46] S. Techakosit and P. Nilsook, "Using Augmented Reality for Teaching Physics," in Proc. The Sixth TCU International eLearning Conference 2015, 2015, pp.282-287.

[47] M. Antonioli, C. Blake, and K. Sparks, "Augmented Reality Applications in Education," Journal of Technology Studies, September 1, 2014, pp. 96-107.

[48] F. Pengcheng, Z. Mingquan and W. Xuesong, "The Significance and Effectiveness of Augmented Reality in Experimental Education," in Proc. E-Business and E-Government (ICEE), 2011, pp.1-4. http://dx.doi.org/10.1109/icebeg.2011.5881654

[49] M. Billinghurst, "Augmented Reality in Education," 2002 [Online]. Available: http://www.solomonalexis.com/downloads/ ar_edu.pdf.

[50] M. Specht, S. Ternier, and W. Greller, "Mobile Augmented Reality for Learning: A Case Study," Journal of the Research Center for Educational Technology (RCET), vol. 7, no. 1, 2011, pp. 117127.

[51] I. Radu, "Why Should My Students Use AR? A Comparative Review of the Educational Impacts of Augmented-Reality," in Proc. IEEE International Symposium on Mixed and Augmented Reality 2012, 2012, pp. 313-314. http://dx.doi.org/10.1109/ ISMAR.2012.6402590

[52] HK Wu, S Wen-Yu Lee, HY Chang and JC Liang, "Current status, opportunities and challenges of augmented reality in education," Computers \& Education, vol.62, 2013, pp. 41-49. http://dx.doi.org/10.1016/j.compedu.2012.10.024

[53] C. C. Kuhlthau, "Guided Inquiry: School Libraries in the $21^{\text {st }}$ Century," School Libraries Worldwide, vol.16, no.1, 2010, pp. 1728.

[54] R. J. Chenail, "When Disney meets the research park: Metaphors and models for engineering an online learning community of tomorrow," Internet and Higher Education, vol.7, 2004, pp. 107121. http://dx.doi.org/10.1016/j.iheduc.2004.03.001

[55] M. Antonioli, C. Blake and K. Sparks, "Augmented Reality Application in Education," The Journal of Technology Studies, vol.40, no.2, 2014. Pp. 96-107. http://dx.doi.org/10.21061/jots. v40i2.a.4

[56] D. B. Sorgi, "STEM Literacy: Fad or Future?," 2016[Online]. Available: Available from: URL: https://www1.iclicker.com/stemliteracy-fad-future/.

\section{AUTHORS}

Somsak Techakosit is a $\mathrm{PhD}$ candidate in Information and Communication Technology for Education, Faculty of Technical Education, King Mongkut's University of Technology North Bangkok (KMUTNB), Bangkok, Thailand, 10800 (e-mail: techakosit@gmail.com).

Prachyanun Nilsook is with the Faculty of Technical

Education, King Mongkut's University of Technology North Bangkok (KMUTNB), Bangkok, Thailand, 10800 (e-mail: prachyanunn@kmutnb.ac.th).

Submitted 12 December 2015. Published as resubmitted by the authors 23 February 2016. 